\title{
Cancer incidence of workers in the Swedish petroleum industry
}

\author{
Bengt Järvholm, Bodil Mellblom, Ritva Norrman, Ralph Nilsson, Rolf Nordlinder
}

Department of

Occupational and

Environmental

Medicine, Umeå

University, Umeå,

Sweden

B Järvholm

\section{Department of}

Occupational

Medicine, Internal

Medicine, Sahlgrenska

Hospital, Gothenburg

University, Göteborg,

Sweden

B Järvholm

$R$ Nilsson

R Nordlinder

TYA, The Vocational

Training and Working

Environment Council of the Transport

Trades, Solna, Sweden

B Mellblom

R Norrman

Correspondence to: Dr Bengt Järvholm,

Department of Occupational and Environmental

Medicine, Umeå University,

S-901 85 Umeå, Sweden.

Accepted 12 March 1997

\begin{abstract}
Objectives-To estimate the risk of cancer due to occupational exposure to petroleum products in the Swedish transport and refinery industries.

Methods-In a retrospective cohort study the cancer incidence in 4128 men and 191 women, who had worked for at least one year in the petroleum industry, was compared with the incidence in the general population. The job titles and employment times for each person were found in personal files in the industries. The men had on average worked in jobs exposed to petroleum for $\mathbf{1 1 . 6}$ years at the end of the observation period. The cases of cancer were identified by record linkage with the Swedish cancer register.
\end{abstract}

Results-In total there were 146 cases of cancer $v 157.6$ expected (standardised mortality ratio (SMR) $0.9390 \%$ confidence interval ( $90 \% \mathrm{CI}) 0.80$ to 1.1$)$. Operators at refineries had an increased risk of leukaemia (6 cases $v 1.7$ expected, $90 \%$ CI of relative risk (RR) 1.5 to 7.0 ). Five of the six cases had started to work at the refineries in the 1950 s or later. No other significantly increased risk of cancer was found. Distribution workers had a decreased incidence of lung cancer (no cases, $90 \%$ CI of RR 0 to 0.4 ).

Conclusions-Operators at Swedish refineries had an increased risk of leukaemia. A possible cause is exposure to benzene. There was no increased risk of leukaemia in distribution workers. Distribution workers had a decreased risk of lung cancer.

(Occup Environ Med 1997;54:686-691)

Keywords: benzene; leukaemia; occupation

Some petroleum products such as gasoline and heavy fuel oils contain cancerous substances such as benzene and polycyclic aromatic hydrocarbons (PAHs). These products have a widespread use and there are many people in several occupational groups who are exposed to benzene or PAHs from petroleum products - for example, refinery workers, distribution workers, workers manufacturing lubrication oils, and tank cleaners. The risk for cancer due to exposures in these industries depends on the type of product used and the dose. Persons handling petrol in Sweden are exposed to benzene. The petrol in Sweden contained benzene in concentrations between $4 \%$ and $7 \%$ by volume since the second world war until the 1960 s and has contained $3 \%$ to $5 \%$ thereafter. This is a higher concentration than in the United States, where it is usually below $1.5 \% .^{1}$ The highest permissible concentration in Sweden today is $5 \%$.

There are studies of refinery workers that show an increased risk of leukaemia and squamous cell skin cancer, attributed to exposure to benzene and PAHs respectively. ${ }^{2-4}$ There are also a few studies of distribution workers exposed to petroleum products. A British study indicated an increased risk of kidney cancer and leukaemia, ${ }^{56}$ a Canadian study indicated an increased risk of leukaemia in tanker drivers, ${ }^{7}$ and a study from the United States indicated an increased risk of acute myeloid leukaemia, although the increase was not significant. ${ }^{8}$

The objective of this study was to estimate the risk of cancer for workers in the Swedish petroleum industry - that is, workers in occupational groups such as refinery workers, terminal workers, distribution workers, tank cleaners, workers manufacturing lubrication oils, and workers exposed to aircraft fuels.

\section{Subjects and methods}

This is a retrospective cohort study in which the cancer incidence in workers in some occupations exposed to petroleum products is compared with the incidence in the general population.

The exposed men were identified from personal files in petroleum industries. To fulfil the criteria for this study the registers should be complete - that is, no personal records should have been eliminated from the registers. Furthermore, the registers should contain information about work tasks and employment times. The original purpose was to have at least 3000 people in the cohort from refineries, distribution companies, lubrication oil manufacturing industries, tank cleaning companies, and companies handling air fuel. In total, people from 26 different companies were included in the study. The year from which the personal registers of these firms could be used varied between 1958 and 1987. The firms were selected according to the criteria already mentioned and a further criterion was that they should have at least 50 employees. During the study we found that all tank cleaning firms had fewer than $\mathbf{5 0}$ workers, so these tank cleaning workers were included. Only people with at least one year of employment up to 1991 with 
a job title indicating exposure to petroleum products were included.

The observation time started when the person had worked for at least one year in an occupation with exposure to petroleum and not before the register of the firm was regarded as being accurate. So if the person started to work in 1966 but the register was accurate only from 1973, the observation period for this person started in 1973. Person-years were calculated until the year of death, the year of emigration, or 1991 whichever came earliest. Furthermore, only person-years between 1958 and 1991 were included. The Swedish cancer register was founded in 1958 and 1991 was the latest year of completeness of that register at the time of the study. However, all periods within these occupational groups were considered in the calculation of employment time.

Incident cases of cancer were found through linkage of the personal numbers with the Swedish cancer register. The causes of death were found through linkage with the Swedish death register. Through linkage with the register of the current Swedish population and a search in the emigration register the present status of each person was categorised as living, dead, emigrated, or lost to follow up. Seven people were lost to follow up and were excluded from the analysis. Fifty people had emigrated.

The expected cancer morbidity and mortality were calculated from cancer incidence or mortality rates for the general population stratified for sex, age, and calendar year according to the person-year method. ${ }^{9}$ In the analysis only person-years between 20 and 84 years of age were considered. $90 \%$ Confidence intervals $(90 \% \mathrm{CIs})$ were calculated assuming a Poisson distribution. Associations in which the $90 \% \mathrm{CI}$ of the relative risk (RR) excluded 1.0 are described as significant.

\section{EXPOSURE}

There has been some personal air sampling in this industry since the 1970 s but not on a random basis. The measurements have sometimes been made during certain work operations in which high levels could be expected. Only a few measurements of eight hour time weighted averages (8hTWA) have been done. At a Swedish refinery, Nordlinder and Ramnäs ${ }^{10}$ found benzene concentrations at a crude oil distillation unit of $0.5-1.3 \mathrm{mg} / \mathrm{m}^{3}(\mathrm{n}=4)$ and $0.1-0.3$ $\mathrm{mg} / \mathrm{m}^{3}(\mathrm{n}=3)$ in workers at a reformer unit in the late 1970 s and the beginning of the 1980 s. The highest concentration was $190 \mathrm{mg} / \mathrm{m}^{3}$ during five minutes of sampling time. During road tanker loading they found $1.0-13 \mathrm{mg} / \mathrm{m}^{3}$ for

Table 1 Number of men in different occupations, year of birth, and average exposure time in 1991

\begin{tabular}{lclr}
\hline Occupation & Men $(n)$ & Year of birth & Exposure time $(y)^{\star}$ \\
\hline Refinery operators & 1339 & $1946(1893-1971)$ & $9.5(1-46)$ \\
Distribution workers & 1391 & $1942(1901-72)$ & $12.1(1-45)$ \\
Manufacturing of lubricants & 308 & $1944(1906-72)$ & $8.8(1-38)$ \\
Tank cleaners & 87 & $1945(1917-73)$ & $13.3(1-37)$ \\
Handling of air fuel & 380 & $1949(1918-72)$ & $10.2(1-44)$ \\
Others & 623 & $1941(1895-1972)$ & $14.1(1-46)$ \\
\hline
\end{tabular}

${ }^{\star}$ Mean (range). top loading in open terminal buildings $(n=16)$ and $0.5-4.0 \mathrm{mg} / \mathrm{m}^{3}$ for bottom loading in open terminal buildings $(n=6)$ with sampling times between five and 15 minutes. Top tank loading of road tankers was successively changed to bottom loading during the 1980 s.

Recent short time measurements (10 to 44 minutes) in Finland during loading and delivery of road tankers with gasoline showed exposures of benzene between $1.1-18 \mathrm{mg} / \mathrm{m}^{3}{ }^{11}$ The highest exposure was seen during top loading at terminals.

Personal sampling in tanks with low boiling point petroleum products during cleaning showed benzene concentrations between 3 and $78 \mathrm{mg} / \mathrm{m}^{3}$ in the mid-1980s. ${ }^{12}$ However, most of the tank cleaners used protective equipment. The work times in the tanks varied between five minutes and 1.5 hours.

Some jobs with high exposure were selected for a separate analysis of cancer, tanker drivers, operators at terminals, production workers in the manufacturing of lubricants, operators at refineries, workers distributing products at refineries, tank cleaners, and workers repairing air craft engines or filling aeroplanes. Operators at refineries were defined as workers involved in supervising the refining process, trouble shooting, and maintenance work. They had job titles of operators or repairmen. Workers at refineries involved with loading and distribution were classified separately. Some workers could not be classified in any of those groups, such as transport workers within the industries, salaried workers who spend part of their time in the shops, laboratory personal, etc.

In the analysis the duration of exposure is determined as the time the workers have had in the jobs with exposure to petroleum products. The onset of exposure is calculated as the time of starting work in such a job.

\section{Results}

A total of 4128 men and 191 women were included in the study. The men were born between 1893 and 1973, with an average duration of exposure up to 1991 of 11.2 years (table 1). The women were on average younger (born 1903-73) and had a shorter duration of exposure (mean 6.0 years).

Four women had cancer versus 3.1 expected (colon cancer, breast cancer, and two cases of ovarian cancer). As the women were few, they were excluded from further analysis.

The analysis of the total group of male workers did not indicate any significantly increased risk of cancer, the incidence of lung cancer was even lower than expected (table 2). The mortality from cancer was not increased. There was no case of death due to aplastic anaemia. The mortality from cardiovascular diseases was slightly lower than expected, and was consistent with a healthy worker effect. Increasing the criteria for duration of exposure and time since onset of exposure did not change these findings.

An analysis according to occupational group showed that there were few cases of cancer in some groups (table 3). As tanker drivers, workers at terminals, and distribution workers at 
Table 2 Cancer morbidity and mortality in all male workers according to duration of exposure and time since onset of exposure

\begin{tabular}{|c|c|c|c|c|c|c|}
\hline & \multicolumn{6}{|c|}{ Duration of exposure; time since onset of exposure } \\
\hline & \multicolumn{2}{|l|}{$\geqslant 1 y ; \geqslant 1 y$} & \multicolumn{2}{|l|}{$\geqslant 1 y ; \geqslant 20 y$} & \multicolumn{2}{|l|}{$\geqslant 10 y ; \geqslant 20 y$} \\
\hline & $\begin{array}{l}\text { SIR or } S M R \\
(90 \% \text { CI) }\end{array}$ & $n$ & $\begin{array}{l}\text { SIR or } S M R \\
(90 \% \text { CI })\end{array}$ & $n$ & $\begin{array}{l}\text { SIR or } S M R \\
(90 \% \mathrm{CI})\end{array}$ & $n$ \\
\hline \multicolumn{7}{|l|}{ Cancer morbidity: } \\
\hline All sites $(140-209)^{\star}$ & $0.93(0.80$ to 1.1$)$ & 146 & $0.88(0.72$ to 1.1$)$ & 77 & $0.88(0.71$ to 1.1$)$ & 70 \\
\hline Nasopharynx (140-149) & $1.2(0.54$ to 2.5$)$ & 6 & $2.0 \quad(0.79$ to 4.2$)$ & 5 & $2.2(0.90$ to 4.8$)$ & 5 \\
\hline Gastrointestinal (150-159) & $0.85(0.62$ to 1.1$)$ & 33 & $0.70(0.44$ to 1.1$)$ & 16 & $0.73(0.45$ to 1.1$)$ & 15 \\
\hline Lung and airways (160-162) & $0.56(0.31$ to 0.92$)$ & 11 & $0.36(0.12$ to 0.82$)$ & 4 & $0.39(0.13$ to 0.90$)$ & 4 \\
\hline Prostate (185) & $1.1 \quad(0.78$ to 1.5$)$ & 30 & $1.0(0.68$ to 1.5$)$ & 20 & $1.0(0.65$ to 1.5$)$ & 18 \\
\hline Kidney and urinary bladder $(188-189)$ & $0.77(0.47$ to 1.2$)$ & 14 & $0.69(0.32$ to 1.3$)$ & 7 & $0.76(0.36$ to 1.4$)$ & 7 \\
\hline Melanoma (172) & $1.1 \quad(0.49$ to 2.0$)$ & 7 & $-\quad(0$ to 1.2$)$ & 0 & $-\quad(0$ to 1.3$)$ & 0 \\
\hline Other skin cancer (173) & $1.3(0.61$ to 2.4$)$ & 7 & $1.8 \quad(0.77$ to 3.5$)$ & 6 & $0.97(0.26$ to 2.5$)$ & 3 \\
\hline Brain (191) & $1.1 \quad(0.51$ to 2.0$)$ & 7 & $1.6 \quad(0.57$ to 3.8$)$ & 4 & $1.8(0.62$ to 4.2$)$ & 4 \\
\hline Lymphoma (200-202) & $0.93(0.48$ to 1.6$)$ & 9 & $0.65(0.18$ to 1.7$)$ & 3 & $0.48(0.08$ to 1.5$)$ & 2 \\
\hline Leukaemia (204-207) & $1.4(0.59$ to 2.7$)$ & 6 & $1.4(0.39$ to 3.7$)$ & 3 & $1.5(0.41$ to 3.9$)$ & 3 \\
\hline \multicolumn{7}{|l|}{ Mortality: } \\
\hline All causes $(000-999)$ & $0.85(0.76$ to 0.94$)$ & 269 & $0.89(0.78$ to 1.0$)$ & 159 & $0.88(0.77$ to 1.0$)$ & 143 \\
\hline Tumours (140-209) & $1.0(0.82$ to 1.2$)$ & 79 & $0.90(0.68$ to 1.2$)$ & 42 & $0.89(0.67$ to 1.2$)$ & 38 \\
\hline Cardiovascular (390-459) & $0.73(0.63$ to 0.86$)$ & 114 & $0.88(0.73$ to 1.1$)$ & 88 & $0.87(0.71$ to 1.1$)$ & 79 \\
\hline Respiratory (460-519) & $1.2(0.76$ to 1.7$)$ & 19 & $1.0 \quad(0.57$ to 1.7$)$ & 11 & $1.0 \quad(0.55$ to 1.7$)$ & 10 \\
\hline Accidents etc (800-999) & $0.84(0.62$ to 1.1$)$ & 34 & $0.58(0.25$ to 1.1$)$ & 6 & $0.55(0.21$ to 1.1$)$ & 5 \\
\hline Person-years & 45514.0 & & 9471.0 & & 8284.5 & \\
\hline
\end{tabular}

$\star$ International classification of diseases, 9 th revision.

refineries have rather similar exposure to petroleum products we merged them into one group, distribution workers. Their main exposure occurred during loading and unloading of petrol, diesel, and fuel oils. We here present the findings in different sites of cancer for two groups, operators at refineries and distribution workers (tables 4 and 5).

The operators at refineries had an increased incidence of leukaemia, whereas the RRs in other sites of cancer were not significantly increased. There were two cases of acute myelocytic leukaemia (durations of exposure nine and 30 years), one case of acute lymphocytic leukaemia (duration of exposure 15 years), and three cases of chronic lymphatic leukaemia (durations of exposure 2, 7, and 20 years). One had started his exposure in the 1940 s (acute myelocytic leukaemia), two in the 1950s (chronic lymphatic leukaemia, acute lymphocytic leukaemia) and three in the 1970s (acute myelocytic leukaemia, two cases of chronic lymphatic leukaemia). The RR for leukaemia was similar when the criteria for time since onset of exposure or duration of exposure increased. The incidence of lung cancer in refinery operators was similar to the expected.

Distribution workers had no significantly increased risks (table 5). There was no case of lung cancer, a significantly decreased incidence compared with the general population.

Table 3 Cancer morbidity (all sites) in men according to occupation in the petroleum industry

\begin{tabular}{lclr}
\hline & & \multicolumn{3}{c}{ Cancer morbidity } \\
\cline { 3 - 4 } Occupation & $n$ & SIR $(90 \%$ CI $)$ & $n$ \\
\hline Operators, refinery & 1339 & $0.99(0.78$ to 1.2$)$ & 57 \\
Distribution, refinery & $203^{\star}$ & $1.4(0.67$ to 2.5$)$ & 8 \\
Terminal operators & $285^{\star}$ & $0.58(0.30$ to 1.0$)$ & 9 \\
Tanker drivers & $907^{\star}$ & $0.71(0.49$ to 1.0$)$ & 24 \\
$\begin{array}{l}\text { Manufacturing of } \\
\text { lubricants }\end{array}$ & 308 & $0.94(0.57$ to 1.5$)$ & 14 \\
Tank cleaners & 87 & $0.42(0.02$ to 2.0$)$ & 1 \\
Handling of air fuel & 380 & $1.1(0.55$ to 2.0$)$ & 8 \\
\hline
\end{tabular}

«Included in the group distribution workers (tables 1, 5, and 6).
A separate analysis of refinery and distribution workers first exposed after 1958 showed similar findings, an increased risk of leukaemia in refinery workers (table 6).

\section{Discussion}

This study indicates that men working with refining and distribution of petroleum products in Sweden had a decreased risk of lung cancer. An increased risk of leukaemia in refinery operators was found but no other significantly increased risks were disclosed.

\section{EXPOSURE}

The exposure assessment of this cohort is based on employment in certain firms and on job titles. As the concentrations can vary considerably between and within workers with similar jobs and with time, any estimation of exposure without personal air sampling is uncertain. ${ }^{13} 14$

All occupational hygienists and safety engineers we have asked consider the present exposure to benzene and other petroleum products to be lower today than 20 years ago in these trades. They base their judgement on better working practice, more exhaust ventilation, and the use of personal protective equipment. However, it is impossible to estimate the average concentration in the 1950 s and 1960s in the absence of measurements. The concentrations of benzene in some Swedish workplaces in the late 1970s and the beginning of the 1980s have been reported by Nordlinder and Ramnäs. ${ }^{10}$ They found that 8hTWA concentrations of benzene in refinery operators were around $0.5 \mathrm{mg} / \mathrm{m}^{3}$ but for short periods higher exposures occurred. The exposure during loading of road tankers was usually higher, but the duration of exposure was shorter. We have 8hTWA samples of benzene only for some process workers in refineries. However, sampling during the late 1970 s and 1980 s may not be representative of the exposure during the 
Table 4 Cancer morbidity in male refinery operators according to exposure time and time since onset of exposure

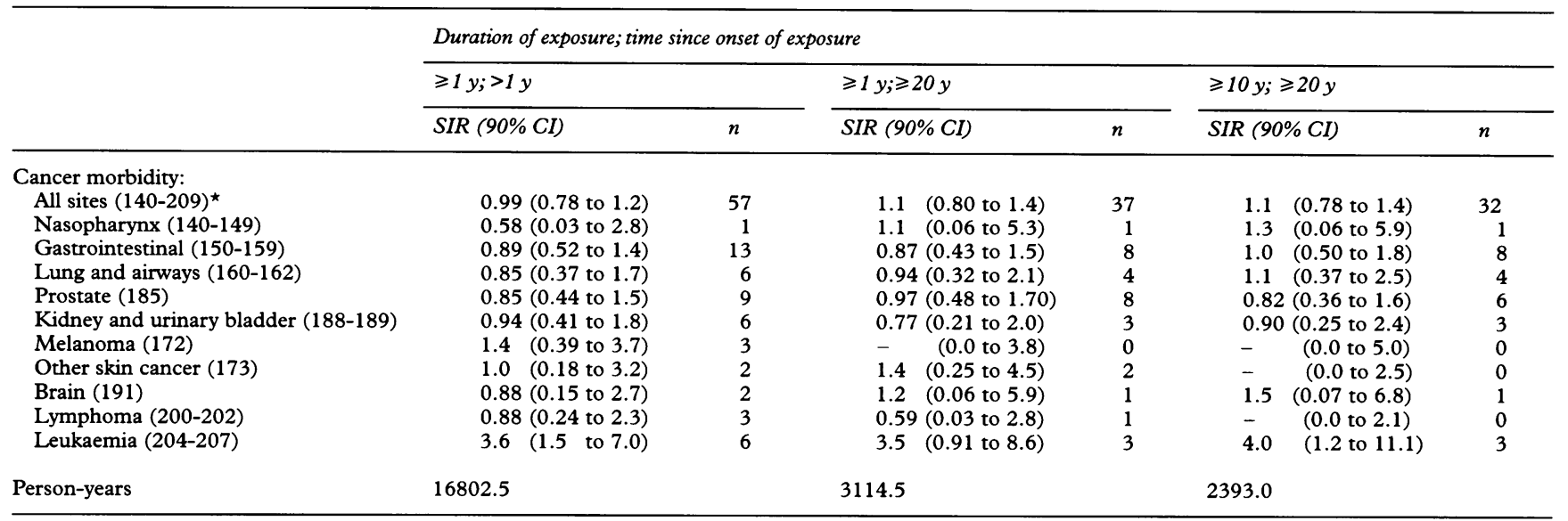

^International classification of diseases, 9th revision.

1950s and 1960s. In the Pliofilm cohort, no case of leukaemia has yet been found in workers with employment after 1950, which has been interpreted as an indication that benzene only causes leukaemia at high exposures. ${ }^{15}$ Five of the six cases of leukaemia in our study had started their exposure in the refineries after 1950.

\section{LEUKAEMIA}

Our finding of an increased risk of leukaemia in refinery operators agrees with some other studies. ${ }^{3}$ The British study of distribution workers in the petroleum industry indicated an increased risk of leukaemia, ${ }^{6}$ and a Canadian study found an increased risk for tanker drivers (standardised mortality ratio (SMR) 3.35 based on five cases). ${ }^{7}$ We found no case of leukaemia in tanker drivers but the size of the study makes the risk estimates rather imprecise ( $90 \% \mathrm{CI}$ of $\mathrm{RR}$ in tanker drivers 0.0 to 3.3). In the combined group of distribution workers, including tanker drivers, workers at terminals, and distribution workers at refineries there was no case of leukaemia ( $90 \%$ CI 0.0 to 2.0 ). A United States study indicated an increased risk of acute myeloid leukaemia but not of other kinds of leukaemia among land based terminal employees. ${ }^{8}$ The differences in risk may be due to variation in exposure. Furthermore in the British and the Canadian studies, a larger proportion of older workers was included than in our cohort and thus they may have worked in periods when poor occupational hygiene and working practice caused higher exposures.

Operators in the Swedish refineries have had varying tasks in the production process at the refineries. They are the workers that manage the production process. This may include waiting and watching instruments, repairing broken pipes, closing valves, inspecting instruments in the process, and repairing and maintaining the equipment during stops in production. During the years the process has been successively more automated meaning that the operators spend more of their time in control rooms today than in earlier days. There are no measurements of their exposure to petroleum products in the $1950 \mathrm{~s}, 1960 \mathrm{~s}$, or early 1970 s but it is probable that they are less exposed to chemicals from the refining process today. Measurements in the late 1970s and the beginning of the 1980 s showed that refinery operators had some exposure to benzene, around $0.5 \mathrm{mg} / \mathrm{m}^{3}$. They were also exposed to other substances in petroleum products that occur in crude mineral oil and additives-for example, alkyl lead-which was added to petrol in the refineries.

A possible cause of the increased risk of leukaemia in the refinery operators is their exposure to benzene. The leukaemogenic effect of benzene is well known. ${ }^{16}$ An increased risk of leukaemia was one of the hypotheses of

Table 5 Cancer morbidity in male distribution workers according to exposure time and time since onset of exposure

\begin{tabular}{|c|c|c|c|c|c|c|}
\hline & \multicolumn{6}{|c|}{ Duration of exposure; time since onset of exposure } \\
\hline & \multicolumn{2}{|l|}{$\geqslant 1 y ; \geqslant 1 y$} & \multicolumn{2}{|l|}{$\geqslant 1 y ; \geqslant 20 y$} & \multicolumn{2}{|l|}{$\geqslant 10 y ; \geqslant 20 y$} \\
\hline & $\operatorname{SIR}(90 \% C I)$ & $n$ & $\operatorname{SIR}(90 \% C I)$ & $n$ & $\operatorname{SIR}(90 \% C I)$ & $n$ \\
\hline All sites $(140-209)^{\star}$ & 0.75 (0.57 to 0.97$)$ & 41 & $0.64(0.42$ to 0.94$)$ & 19 & 0.68 (0.44 to 1.0$)$ & 18 \\
\hline Nasopharynx (140-149) & $1.8 \quad(0.48$ to 4.6$)$ & 3 & $2.3 \quad(0.40$ to 7.0$)$ & 2 & $2.5 \quad(0.44$ to 7.9$)$ & 2 \\
\hline Gastrointestinal (150-159) & $0.90(0.52$ to 1.5$)$ & 12 & $0.53(0.18$ to 1.2$)$ & 4 & $0.45(0.12$ to 1.2$)$ & 3 \\
\hline Lung and airways (160-162) & $-\quad(0$ to 0.43$)$ & 0 & $-\quad(0$ to 0.77$)$ & 0 & $-\quad(0$ to 0.86$)$ & 0 \\
\hline Kidney and urinary bladder $(188-189)$ & $0.62(0.21$ to 1.4$)$ & 4 & $0.57(0.10$ to 1.8$)$ & 2 & $0.63(0.11$ to 2.0$)$ & 2 \\
\hline Melanoma (172) & $0.41(0.02$ to 1.9$)$ & 1 & $-\quad(0$ to 3.0$)$ & 0 & $-\quad(0$ to 3.3$)$ & $\overline{0}$ \\
\hline Other skin cancer (173) & $1.6(0.43$ to 4.1$)$ & 3 & $1.8 \quad(0.32$ to 5.7$)$ & 2 & $2.1 \quad(0.36$ to 6.3$)$ & 2 \\
\hline Brain (191) & $1.3(0.36$ to 3.4$)$ & 3 & $2.2(0.40$ to 7.0$)$ & 2 & $2.4 \quad(0.44$ to 7.9$)$ & 2 \\
\hline Lymphoma (200-202) & $0.29(0.02$ to 1.4$)$ & 1 & (0 to 1.8$)$ & 0 & (0 to 2.0 ) & 0 \\
\hline Leukaemia (204-207) & $-\quad(0$ to 2.0$)$ & 0 & ( 0 to 4.3 ) & 0 & (0 to 5.0 ) & 0 \\
\hline Person-years & 14874.5 & & 3637.5 & & 3219.0 & \\
\hline
\end{tabular}

${ }^{\star}$ International classification of diseases, 9 th revision. 
Table 6 Cancer morbidity in male refinery operators and distribution workers who have been exposed only after 1958

\begin{tabular}{|c|c|c|c|c|}
\hline & \multicolumn{2}{|l|}{ Refinery workers } & \multicolumn{2}{|l|}{ Distribution workers } \\
\hline & $\operatorname{SIR}(90 \% \mathrm{CI})$ & $n$ & $\operatorname{SIR}(90 \% C I)$ & $n$ \\
\hline All sites $(140-209)^{\star}$ & $0.90(0.6$ to 1.3$)$ & 21 & $0.70(0.5$ to 1.0$)$ & 24 \\
\hline Nasopharynx (140-149) & $-\quad(0$ to 4.3$)$ & 0 & $1.8(0.3$ to 5.7$)$ & 2 \\
\hline Gastrointestinal (150-159) & $0.98(0.4$ to 3.1$)$ & 5 & $0.76(0.3$ to 1.5$)$ & 6 \\
\hline $\begin{array}{l}\text { Lung and airways } \\
(160-162)\end{array}$ & $0.74(0.1$ to 2.3$)$ & 2 & - (0 to 0.7$)$ & 0 \\
\hline Prostate (185) & $1.1 \quad(0.3$ to 2.8$)$ & 3 & $0.60(0.2$ to 1.6$)$ & 3 \\
\hline $\begin{array}{l}\text { Kidney and urinary } \\
\text { bladder (188-189) }\end{array}$ & $0.78(0.1$ to 2.4$)$ & 2 & 0.50 (0.1 to 1.6$)$ & 2 \\
\hline Melanoma (172) & $1.4(0.2$ to 4.2$)$ & 2 & $0.53(0.0$ to 2.5$)$ & 1 \\
\hline Other skin cancer (173) & $-\quad(0$ to 4.3$)$ & 0 & 2.7 (0.7 to 7.1$)$ & 3 \\
\hline Brain (191) & $0.72(0.0$ to 3.4$)$ & 1 & $1.2(0.2$ to 3.7$)$ & 2 \\
\hline Lymphoma (200-202) & $1.2(0.2$ to 3.7$)$ & 2 & $0.42(0.0$ to 2.0$)$ & 1 \\
\hline Leukaemia (204-207) & 4.0 (1.2 to 11.1$)$ & 3 & $-\quad(0$ to 3.0$)$ & 0 \\
\hline Person-years & 13161.0 & & 12652.0 & \\
\hline
\end{tabular}

^International classification of diseases, 9 th revision.

this study. Earlier studies have indicated that mainly acute non-lymphocytic leukaemia is causally linked to benzene. ${ }^{17-19}$ In a recent review Infante states that there is "evidence that all of the major cell types of leukaemia and some of the more rare types are associated with benzene exposure. ${ }^{20}$ Wong ${ }^{2122}$ states that there is lack of evidence of an association between benzene and other cell types than acute myeloid leukaemia, whereas Savitz and Andrews $^{23}$ are of an opposite opinion. In a recent study from China, workers exposed to benzene had an increased risk of several types of leukaemia. ${ }^{24}$ Two of the six cases in our study were acute non-lymphocytic leukaemia. We are not able to give any accurate exposure estimate of benzene or other chemicals of these cases for leukaemia.

\section{LUNG CANCER}

There was a low risk of lung cancer especially among the distribution workers. Our findings are partly supported by other studies. Schnatter et al found non-significantly decreased risk in tanker drivers (SMR 0.79, 95\% CI 0.36 to 1.50). Rushton ${ }^{5}$ found a slightly decreased risk of lung cancer in distribution workers (SMR $0.89,95 \%$ CI 0.83 to 0.95 ) and a United States study found a decreased risk of lung cancer (SMR 0.66, 95\% CI 0.57 to 0.77 ) in land based terminal workers. ${ }^{8}$ Thus, the low risk of lung cancer seems to be sustained by other studies. One explanation may be that smoking is prohibited during the handling of petrol. A cross sectional study of smoking habits in 102 Swedish tanker drivers in 1990 showed, however, that there were more smokers in this group than in the general population. ${ }^{25}$ If that finding is representative of the workers in this cohort, lower smoking habits seem to be a less probable cause of the low incidence of lung cancer. Thus, there seems to be no obvious explanation for the decreased risk of lung cancer in distribution workers.

OTHER SITES OF CANCER AND CAUSES OF DEATH Our findings do not indicate any increased risk of cancer in the other occupational groups but the study has little statistical power to detect cancer risks in specific jobs or more rare sites.
The mortality of this cohort was close to that expected. The handling of highly inflammable products and the driving of tankers had not increased the risk of accidents in distribution workers. There was no case of death due to aplastic anaemia, a well known result of high exposure to benzene. There are, however, no registers in Sweden where non-fatal anaemia among these workers can be found.

\section{ASPECTS OF VALIDITY}

The cohort was identified through personal files at the companies, and if individual people that had died or developed cancer were withdrawn from the files this would cause a decreased risk. Therefore, only companies with personal registers without withdrawals were included.

As the loss to follow up was low $(n=7)$, risk estimates will not have been substantially influenced. Emigration would also be unlikely to cause any bias of cancer incidence as a diagnosed case of cancer that emigrates still will occur in the cancer register.

The causes of death and the cancer sites were found by linking the death register to the cancer register making a diagnostic bias improbable. Most cases of cancer are diagnosed by microscopical examinations and the physician making that examination was rarely aware of the patients' exposure to chemicals. Many of the petroleum workers lived in densely populated areas and if there is a difference in diagnostic procedures and accuracy between different areas this may cause a bias. We think it is improbable that such diagnosic differences would explain the findings in refinery operators. Most cases of leukaemia in Sweden are diagnosed and treated by specialists in large hospitals.

The incidence in these workers was compared with the corresponding incidence in the general population. Due to healthy worker selection, the mortality should be lower among exposed subjects if they had no increased mortality. ${ }^{26}{ }^{27}$ However, this selection bias is much weaker, if present, when cancer incidence is studied than - for example, death from cardiovascular disease. Mortality studies have shown that healthy worker selection is less for mortality from cancer than from other causes. ${ }^{28}$

In summary, this study indicates that Swedish refinery workers have an increased risk of leukaemia probably due to their exposure to benzene. The study does not indicate an increased risk of cancer in other Swedish petroleum workers - such as tanker drivers or distribution workers. The number of cases of lung cancer was lower than expected among these groups.

1 Alkand G. Exposure of the general population to gasoline. Environ Health Perspect 1993;101(suppl 6):27-32.

2 Christie D, Robinson K, Gordon I, Bisby J. A prospective study in the Australian petroleum industry. II Incidence of cancer. $\mathrm{Br}$ F Ind Med 1991;48:511-4.

3 International Agency for Research on Cancer. IARC monographs on the evaluation of the carcinogenic risk of chemicals to humans. Occupational exposures in petroleum refining. Lyon: IARC, 1989;45:81-117.

4 Wong O, Raabe GK. Critical review of cancer epidemiology in petroleum industry employees, with a quantitative metaanalyses by cancer site. Am f Ind Med 1989;15:283-310. 
5 Rushton L. Further follow up of mortality in a United Kingdom oil distribution centre cohort. $\mathrm{Br} f$ Ind $M e d$ 1993;5:561-9.

6 Rushton L. A 39-year follow-up of the UK oil refinery and distribution centre studies: results for kidney cancer and leukemia. Environ Health Perspect 1993;101(suppl 6):7784.

7 Schnatter AR, Katz M, Nicolich MJ, Thériault G. A retrospective mortality study among Canadian petroleum marketing and distribution workers. Environ Health Perspect 1993;101 (suppl 6):85-99.

8 Wong $\mathrm{O}$, Harris F, Smith T. Health effects of gasoline exposure. II Mortality patterns of distribution workers in the Sure. II Mortality patterns of distribution workers in the 6):63-76.

9 Berry G. The analysis of mortality by the subject-years method. Biometrics 1983;39:173-84.

10 Nordlinder R, Ramnäs O. Exposure to benzene at different work places in Sweden. Ann Occup Hyg 1987;31:345-55.

11 Hakkola M, Saarienen L. Exposure of tanker drivers to gasoline and some of its components. Ann Occup Hyg 1996;40:1-10.

12 Lillienberg L, Högstedt B, Järvholm B, Nilsson L. Health effects of tank cleaners. Am Ind Hyg Assoc $\mathcal{F}$ 1992;53:37580.

13 Kromhout H, Symanski, Rappaport SM. A comprehensive evaluation of within- and between-worker components of occupational exposure to chemical agents. Ann Occup Hyg 1993;37:253-70.

14 Rappaport SM, Kromhout H, Symanski E. Variation of exposure between workers in homogeneous exposure exposure between workers in homogeneo

15 Paxton MB, Chinchiilli VM, Brett SM, Rodricks JV. Leukemia risk associated with benzene exposure in the Pliofilm cohort: 1 Mortality update and exposure distribution. Risk analysis 1994;14:147-54.

16 Rinsky RA, Smith AB, Hornung R, Filloon TG, Young RJ, Okun AH, Landrigan PJ. Benzene and leukemia: an epidemiologic risk assessment. N Engl f Med 1987;316:1044-50.

17 Aksoy M, Erdem S, Dincol B. Types of leukemia in a chronic benzene poisoning: a study in thirty four patients.
Acta Hematol 1976;55:65-72.

18 Brandt L, Nilsson PG, Mitelman F. Occupational exposure to petroleum products in men with acute non-lymphocytic leukemia. BMF 1978;i:553.

19 Infante PF, Wagoner JK, Rinsky RA, Young RJ. Leukaemia in benzene workers. Lancet 1977;ii:76-8.

20 Infante PF. Benzene and leukemia: cell types, latency, and amount of exposure associated with leukemia. In: Imbriani M, Ghittori S, Pezzagno G, Capodaglio E, eds. Advances in occupational medicine and rehabilitation. Update on benzene. Pavia, Italy: Foudazione Salvatore Maugeri Editizione. 1995;1:107-20.

21 Wong $O$. Risk of myelogenous leukaemia and multiple myeloma in workers exposed to benzene [letter]. Occup Environ Med 1995;52:380-4.

22 Wong O. Risk of myelogenous leukaemia and multiple myeloma in workers exposed to benzene [letter]. Occup Environ Med 1996;53:357-8.

23 Savitz DA, Andrews KW. Risk of myelogenous leukaemia and multiple myeloma in workers exposed to benzene [letter]. Occup Environ Med 1996;53:357.

24 Yin SN, Hayes RB, Linet MS, Li GL, Dosemeci M, Travis LB. A cohort study of cancer among benzene-exposed workers in China: overall results. $\mathrm{Am} f$ Ind Med 1996;29:227-35.

25 Wallin M, Berggren M, Bergstrand L. Handling of petrol and petroleum products. Work environment and health in tank truck drivers, tank cleaners, lubrication manufacturing workers, and terminal workers. Stockholm: Transporthälsan, 1990. (In Swedish.)

26 Fox AJ, Collier PF. Low mortality rates in industrial cohort studies due to selection for work and survival in the industry. British gournal try. British fournal of Preventive and Social Medicine

27 McMichael AJ. Standardized mortality ratios and the "healthy worker effect": scratching beneath the surface. $\mathcal{F}$ Occup Med 1976;18:165-8.

28 Monson RR. Observations on the healthy worker effect. $f$ Occup Med 1986;28:425-33.

\section{Occupational and Environmental Medicine and the electronic age}

OEM has an Email address which is 100632.3615@compuserve.com. We welcome contact by Email, including letters to the editor. Some of our reviewers already send us their reports by Email, helping to speed up the peer review process.
Our publishing system is now fully electronic, and authors are sending their revised copy to us on disk as well as paper. Watch for revised Instructions to Authors.

The Editor 